\title{
Uspešnost črpanja evropskih sredstev za razvoj podeželja v Sloveniji v obdobju 2003-2009
}

UDK: $339.727 .22: 338.43(497.4)(045)$

\author{
Aleksander Aristovnik \\ Univerza v Ljubljani, Fakulteta za upravo \\ aleksander.aristovnik@fu.uni-lj.si \\ Maja Žibert \\ maja_zibert@hotmail.com
}

\section{IZVLEČEK}

Skupna kmetijska politika je že več kot štirideset let najpomembnejša skupna evropska politika. Kmetijstvo je edini sektor, ki se v celoti sofinancira iz proračuna EU. Velik delež proračuna EU je namenjen izvajanju skupne kmetijske politike, čeprav se ta delež v zadnjih letih zmanjšuje. Leta 1984 je ta delež predstavljal $77 \%$ vseh sredstev proračuna EU, danes predstavlja $40 \%$, leta 2013 pa bo samo še približno 33 \%. Začetki politike razvoja podeželja v RS segajo v 80. leta prejšnjega stoletja, ko so se začeli izvajati prvi strukturni ukrepi za razvoj podeželja. Večji pomen pa je politika razvoja podeželja dobila leta 1993, ko je bila sprejeta prva strategija razvoja slovenskega kmetijstva. Politika razvoja podeželja v Sloveniji je glede financiranja začela pridobivati pomen šele leta 2003 oziroma šele takrat, ko so se ukrepi politike razvoja podeželja začeli sofinancirati iz proračuna EU. Od leta 2003 so se v Sloveniji izvajali štirje programi razvoja podeželja, ki so bili sofinancirani iz sredstev EU. To so bili program SAPARD, Enotni programski dokument 2004-2006, Program razvoja podeželja 2004-2006 in Program razvoja podeželja 2007-2013. RS je bila pri črpanju sredstev za razvoj podeželja v obdobju 2003-2009 relativno uspešna, še zlasti to velja na področju kmetijsko okoljskih plačil, vendar pa so $v$ trenutno veljavnem programskem obdobju potrebne izboljšave oziroma odprava določenih težav pri posameznih ukrepih.

$\begin{aligned} \text { Ključne besede: } & \text { SAPARD, EPD, program razvoja podeželja, uspešnost, črpanje } \\ & \text { sredstev EU, politika razvoja podeželja }\end{aligned}$

JEL:F15, F36, Q14

Aristovnik, A. \& Žibert, M. (2012). Uspešnost črpanja evropskih sredstev za razvoj podeželja v Sloveniji v obdobju 2003-2009. Uprava/Administration X(3), 75-91. 


\section{Uvod}

Že več kot 40 let je skupna kmetijska politika (v nadaljevanju: SKP) najpomembnejša evropska skupna politika. Kmetijstvo je edini sektor, ki se v celoti financira iz proračuna EU. To pomeni, da evropska sredstva nadomeščajo nacionalna sredstva. Velik del proračuna EU je zato namenjen ravno izvajanju SKP, čeprav se ta delež iz leta v leto zmanjšuje. Tako je bil leta 1984 ta delež $71 \%$, danes predstavlja $40 \%$, leta 2013 pa bo padel samo še na približno $33 \%$ skupnega proračuna EU. V trenutnem finančnem okviru 2007-2013 sredstva za pospeševanje rasti in zaposlovanje prvič presegajo sredstva, ki so na voljo za izvajanje SKP. Izdatki za financiranje kmetijske politike danes prihajajo iz dveh skladov, ki sta del splošnega proračuna EU, in sicer iz Evropskega kmetijskega jamstvenega sklada ter iz Evropskega kmetijskega sklada za razvoj podeželja (v nadaljevanju: EKSRP). Iz prvega se financirajo neposredna plačila kmetom, ukrepi za ureditev kmetijskih trgov (izvozne podpore, intervencijski ukrepi itd.), medtem ko se iz drugega sklada financirajo programi razvoja podeželja v državah članicah (v nadaljevanju: članicah). Za finančno obdobje 2007-2013 je za financiranje celotne kmetijske politike predvidenih 862,4 milijarde EUR, od katerih je za razvoj podeželja namenjenih 88,3 milijard oziroma 10,2 \% (European Commission, 2007; European Commission, 2007a; Evropska komisija, 2011b).

Republika Slovenija (v nadaljevanju: RS) je prva evropska sredstva za razvoj podeželja začela črpati leta 2003 v okviru Posebnega predpristopnega programa za kmetijstvo in razvoj podeželja (programa SAPARD). Po vstopu $\checkmark$ EU je RS črpala evropska sredstva na podlagi Enotnega programskega dokumenta (v nadaljevanju: EPD), Programa razvoja podeželja 2004-2006 (v nadaljevanju: PRP 2004-2006) in Programa razvoja podeželja 2007-2013 (v nadaljevanju: PRP 2007-2013).

Namen članka je bil analizirati uspešnost črpanja evropskih sredstev za razvoj podeželja, ki so bili namenjeni RS od leta 2003 pa do konca leta 2009. Glede na to, da je politika razvoja podeželja del SKP, pa je bil tudi namen analizirati, kako je in kako je bila RS uspešna pri črpanju sredstev v primerjavi z drugimi članicami EU. Torej tudi ugotoviti, ali je bila RS pri črpanju sredstev programa razvoja podeželja v letih od 2003 do 2009 uspešna in kako uspešna je bila RS pri črpanju teh sredstev v primerjavi z drugimi članicami.

Pri pripravi članka je bila kot glavna metoda raziskovanja uporabljena metoda dokazovanja, v katero so vključeni tudi naslednje metode raziskovanja in metodološki pristopi: induktivna in deduktivna metoda, generalizacija in specializacija, analiza in sinteza (Zelenika, 2000, str. 334). Pri primerjavi podatkov o črpanju med posameznimi članicami EU pa sta bili uporabljeni tudi deskriptivna metoda in komparativna metoda oziroma metoda primerjanja ter statistična metoda. 
V članku sta naprej predstavljeni skupna kmetijska politika in politika razvoja podeželja v EU in v RS, nato sledi analiza črpanja sredstev programa razvoja podeželja od leta 2003 od leta 2006 ter analiza črpanja sredstev razvoja podeželja na podlagi Programa razvoja podeželja 2007-2013. Analizi sledita predstavitev ukrepov za boljše črpanje sredstev v RS in zaključek.

Slovenija je tako kot druge nove članice z vstopom v EU spoznala, da so evropska sredstva najpomembnejši vir financiranja različnih ukrepov, projektov oziroma politik. Zato se vse članice v EU trudijo, da se črpanje v vsakem naslednjem programskem obdobju izboljšuje (Markovič Hribernik et al., 2008, str. 1220).

\section{Skupna kmetijska politika in politika razvoj podeželja v EU in RS}

\subsection{Skupna kmetijska politika in politika razvoja podeželja v EU}

Že od samega začetka oblikovanja evropske integracije, torej od leta 1958 naprej, je glavni cilj EU zmanjšanje gospodarskih in socialnih razlik med regijami ter članicami. Pri tem ima pomembno vlogo tudi SKP (Heijman \& Koch, 2011, str. 49). Ukrepe za uresničevanje ciljev SKP razvrščamo v dve skupini oziroma dva stebra. Bistvo SKP predstavlja prvi steber, ki ga sestavljata dva dela, in sicer neposredna plačila in skupne tržne ureditve. SKP je postopoma prevzemala naloge tudi na področju razvoja podeželja, ki predstavlja drugi steber SKP. Ukrepi razvoja podeželja so po letu 2005 postali samostojna politika EU, navezana tako na prvi steber skupne kmetijske politike kot tudi na regionalno in strukturno politiko EU (Erjavec et al., 2007, str. 14-15).

Teoretično bi se posamezne članice EU lahko odločile za popolnoma samostojne politike razvoja podeželja. Vendar pa bi to v praksi slabo delovalo, saj si vsaka članica ne bi mogla privoščiti politike, kijo potrebuje. Veliko področij, ki jih obravnava politika razvoja podeželja, namreč presega nacionalne in regionalne meje ter vplive na ljudi v drugih članicah. Poleg tega se vsaka članica srečuje z različnimi fizičnimi, klimatskimi in socialno-ekonomskimi ovirami v svoji državi ter z različno stopnjo razvitosti posameznih kmetijskih panog. Iz vseh teh razlogov ima zato EU skupno politiko razvoja podeželja, ki pa vseeno daje velike pristojnosti članicam (Evropska komisija, 2011a; Council for the Rural Area, 2010). Vsaka članica ima drugačne težave v kmetijstvu, različne so stopnje razvitosti in konkurenčnosti in zato so programi med seboj različni. Glede na različno stopnjo razvitosti so nato članice izbrale tudi različne ukrepe, s katerimi so poskušale svoje kmetijstvo in podeželje narediti bolj razvito in konkurenčno (European Commission, 2000).

\subsection{Politika razvoja podeželja v RS}

RS je nekatere strukturne ukrepe za razvoj podeželja začela izvajati že v osemdesetih letih 20. stoletja. Večji pomen je politika razvoja podeželja dobila leta 1993, ko je bila sprejeta Strategija razvoja slovenskega kmetijstva. S tem 
dokumentom je bila kmetijstvu prvič priznana večnamenska vloga. Kmetijstvo od takrat dalje nima več samo tradicionalne vloge, to je proizvodnjo hrane, temveč mu je priznana tudi pomembna vloga na področju varstva okolja, prostorska vloga in socialna vloga (Računsko sodišče, 2010). Z vstopom RS $\checkmark$ EU je samostojno izvajanje kmetijske politike nadomestila SKP EU. Politika razvoja podeželja v RS je v finančnem smislu začela pridobivati pomen šele leta 2003 oziroma šele takrat, ko so se ukrepi politike razvoja podeželja začeli financirati iz proračuna EU. Od leta 2003 so se v RS izvajali štirje programi razvoja podeželja, ki so bili sofinancirani iz sredstev EU. Programski dokumenti za črpanje sredstev razvoja podeželja v RS so bili v obdobju 2003-2009 naslednji (Računsko sodišče, 2010):

- program SAPARD,

- EPD 2004-2006,

- PRP 2004-2006 in

- PRP 2007-2013.

\section{Uspešnost črpanja sredstev za razvoj podeželja v RS v obdobju 2003-2009}

\subsection{Uspešnost črpanja sredstev za razvoj podeželja od leta 2003 do leta 2006}

Od leta 2003 pa do konca leta 2006 je RS izplačevala sredstva za razvoj podeželja na podlagi treh programskih dokumentov in sicer: programa SAPARD, EPD 2004-2006 in PRP 2004-2006.

Program SAPARD je bil namenjen pripravi kmetijskega sektorja in podeželskih območij v državah kandidatkah za članstvo v EU (European Commission, 2000a str. 1). Program SAPARD je bil posebna predpristopna pomoč EU za področje kmetijstva in razvoja podeželja, s katerim je EU želela zagotoviti posebno pomoč državam, ki so zaprosile za pristop k EU, z namenom, da bi podprla tedanje procese gospodarske in družbene reforme $v 10$ državah prosilkah ter jih pripravila ter olajšala integracijo njihovih gospodarstev v gospodarstvo EU (glej Trdan, 2002, str. 19). RS je začela črpati sredstva za izvajanje ukrepov politike razvoja podeželja EU na podlagi predpristopnega programa SAPARD leta 2003. Pristojno ministrstvo ${ }^{1}$ je finančne podpore iz tega programa usmerilo v izvajanje ukrepov za izboljšanje konkurenčnosti kmetijskega sektorja, v gospodarsko diverzifikacijo ter izboljšanje podeželske infrastrukture (Računsko sodišče, 2010; Računsko sodišče, 2010c).

1 Od leta 2003 do 3.2. 2012 je bilo to Ministrstvo za kmetijstvo, gozdarstvo in prehrano. Po 4. 2. 2012 je to Ministrstvo za kmetijstvo in okolje (v nadaljevanju: MKO). 
Tabela 1: Višina načrtovanih in izplačanih sredstev za izvajanje posameznih ukrepov programa SAPARD v RS v EUR

\begin{tabular}{|l|c|c|c|}
\hline Ukrep & $\begin{array}{c}\text { Načrtovana sredstva } \\
\text { v EUR* }\end{array}$ & $\begin{array}{c}\text { Izplačana sredstva } \\
\text { v EUR* }\end{array}$ & $\begin{array}{c}\text { Delež izplačanih } \\
\text { sredstev glede na } \\
\text { načrtovana sredstva }\end{array}$ \\
\hline Ukrep 1 & 13.208 .221 & 15.218 .943 & $115 \%$ \\
\hline Ukrep 2 & 15.095 .105 & 16.584 .274 & $110 \%$ \\
\hline Ukrep 5 & 5.283 .488 & 5.513 .985 & $104 \%$ \\
\hline Ukrep 12 & 4.105 .412 & 4.793 .678 & $117 \%$ \\
\hline Ukrep 15 & 282.808 & 99.357 & $35 \%$ \\
\hline SKUPAJ & 37.975 .033 & 42.210 .236 & $111 \%$ \\
\hline
\end{tabular}

* tečaj 1 SIT $=239,64$ EUR

Vir: MKO (2007, str. 36)

RS se je odločila za izvajanje 5 od 15 ukrepov programa SAPARD. Ti so bili: Naložbe v kmetijska gospodarstva (Ukrep 1), Naložbe v predelavo in trženje kmetijskih in ribiških proizvodov (Ukrep 2), Gospodarska diverzifikacija na kmetiji (Ukrep 5), Razvoj in izboljšanje infrastrukture na podeželju (Ukrep 12) in Tehnična pomoč (Ukrep 15). Iz tabele 1 je razvidno, da je RS upravičencem do plačil za posamezne ukrepe skupaj izplačala 42,2 mio EUR, kar pomeni, da je izplačala 4,2 mio EUR več, kot je načrtovala. To pomeni $11 \%$ več, kot je načrtovala. Do največjega odstopanja med izplačanimi in načrtovanimi sredstvi je prišlo pri Ukrepu 12, kjer je bilo izplačanih kar 17 \% več sredstev, kot je bilo načrtovanih. Za Ukrep 15 je bilo izplačanih 65 \% manj sredstev, kot jih je bilo načrtovanih, vendar pa gre tu za poseben ukrep, pri katerem ne kandidirajo isti prosilci kot pri ostalih ukrepih, saj je ta ukrep namenjen predvsem državi za promocijo in različne analize v okviru izvajanja programa SAPARD. Glede na to, da je pri drugih ukrepih prišlo do večjega črpanja, kot je bilo načrtovano, je MKO odstopilo od načrtovanih analiz oziroma ukrepov, ki jih je načrtovalo v okviru Ukrepa 15, saj je že tako primanjkovalo razpoložljivih sredstev.

V nadaljevanju je predstavljena stopnja črpanja sredstev med članicami, ki so leta 2004 postale članice EU in so prav tako kot RS izvajale program SAPARD. Iz tabele 2 je razvidno, da članice na začetku izvajanja programa SAPARD niso izplačale skoraj nič sredstev. Zlasti to velja za prvo leto izvajanja programa, ko prav nobena članica ni izplačala sredstev za izvajanje posameznih ukrepov. Dve članici, in sicer Malta in Ciper, programa SAPARD nista izvajali. 
Tabela 2: Stopnja izplačanih sredstev po posameznih letih za izvajanje programa SAPARD 2000-2006

\begin{tabular}{|l|r|r|r|r|l|}
\hline Država/leto & 2000 & 2001 & 2002 & 2003 & 2006 \\
\hline Češka & $0 \%$ & $0 \%$ & $0 \%$ & $0 \%$ & $95 \%$ \\
\hline Estonija & $0 \%$ & $24 \%$ & $51 \%$ & $130 \%$ & $95 \%$ \\
\hline Madžarska & $0 \%$ & $0 \%$ & $23 \%$ & $0 \%$ & $95 \%$ \\
\hline Litva & $0 \%$ & $24 \%$ & $10 \%$ & $77 \%$ & $95 \%$ \\
\hline Latvija & $0 \%$ & $24 \%$ & $12 \%$ & $89 \%$ & $95 \%$ \\
\hline Poljska & $0 \%$ & $0 \%$ & $23 \%$ & $55 \%$ & $95 \%$ \\
\hline Slovenija & $0 \%$ & $24 \%$ & $1 \%$ & $81 \%$ & $95 \%$ \\
\hline Slovaška & $0 \%$ & $0 \%$ & $23 \%$ & $24 \%$ & $95 \%$ \\
\hline EU-10 & $0 \%$ & $5 \%$ & $20 \%$ & $50 \%$ & $95 \%$ \\
\hline
\end{tabular}

Vir: European Union (2007, str. 341) in lastni izračuni

Bolje je bilo v letu 2001, ko so štiri članice izplačale 24 \% načrtovanih sredstev, med njimi je bila tudi RS. Skupaj je bilo izplačanih le $5 \%$ vseh načrtovanih sredstev. Veliko bolje je bilo v letih 2002 in 2003. Zelo uspešna je bila Estonija, ki je leta 2003 izplačala $30 \%$ več, kot je načrtovala. RS je bila med bolj uspešnimi državami, saj je bila leta 2003 glede na izplačana sredstva na tretjem mestu, takoj za Estonijo in Latvijo. Za leti 2004 in 2005 javno dostopni podatki glede črpanja niso bili najdeni. Na koncu obdobja so vse države izplačale 95 \% načrtovanih sredstev, kar lahko ocenimo kot izjemno uspešno.

Po vstopu RS v EU leta 2004 se je program SAPARD nadaljeval z ukrepi 3. prednostne naloge programa EPD 2004-2006, ki so zajemali prestrukturiranje kmetijstva, gozdarstva in ribištva. $V$ okviru tega programa se je izvajalo 7 ukrepov, od tega pet za področje kmetijstva in dva za področje ribištva. EPD 2004-2006 se je tako kot program SAPARD sofinanciral iz sredstev Evropskega kmetijskega usmerjevalnega in jamstvenega sklada (v nadaljevanju: EKUJS), in sicer iz usmerjevalnega dela. Ukrepi so bil usmerjeni predvsem v prestrukturiranje kmetijskega sektorja, povečanje konkurenčnosti in izboljšanje trženja. Pri ukrepih EPD 2004-2006 je šlo za ukrepe, pri katerih je bil poudarek na razvojnem vidiku. Za izvajanje ukrepov s področja kmetijstva je bilo namenjenih 47,1 mio evrov, kar predstavlja $15 \%$ vseh razpoložljivih sredstev EPD (Računsko sodišče, 2010; Wostner, 2005, str. 64-65).

Iz tabele 3 je razvidno, da je bila višina sredstev, ki so bila izplačana na koncu, nekoliko drugačna od načrtovanih. Razvidno je, da je RS največ sredstev izplačala za ukrep 3.2. (Naložbe v kmetijska gospodarstva), in sicer 16,8 mio EUR, kar predstavlja 33 \% vseh sredstev, ki so bila izplačana za izvajanje tretje prednostne naloge EPD 2004-2006 (Služba Vlade RS za lokalno samoupravo in regionalno politiko, 2010, str. 57). Za ukrep 3.1. (Izboljšanje predelave in trženja kmetijskih proizvodov) je bilo izplačanih manj sredstev od načrtovanih, in sicer 16,1 mio EUR, kar predstavlja 31 \% vseh sredstev, ki so bila izplačana 
za izvajanje tretje prednostne naloge EPD 2004-2006. Na področju ribištva je bilo za ukrep 3.7. (Ribogojstvo, predelava in trženje) izplačanih več sredstev, kot je bilo načrtovanih, saj je bilo izplačanih 4,9 mio EUR, načrtovanih pa 4,2 mio EUR. Obratno je bilo pri ukrepu 3.6. (Posodobitev obstoječih plovil in mali priobalni ribolov), kjer je bilo izplačanih 310.949 EUR, načrtovanih pa 408.159 EUR (Služba Vlade RS za lokalno samoupravo in regionalno politiko, 2010, str. 57). Priukrepih 3.3. (Diverzifikacija kmetijskih dejavnosti in dejavnosti, ki so blizu kmetijstvu), 3.4. (Investicije v gozdove za izboljšanje gospodarske in ekološke vrednosti gozdov) in 3.5. (Trženje kakovostnih kmetijskih in živilskih proizvodov) je RS izplačala vsa načrtovana sredstva.

Tabela 3: Višina načrtovanih in izplačanih sredstev za izvajanje posameznih ukrepov EPD 2004-2006 v RS v EUR

\begin{tabular}{|l|c|c|}
\hline & Načrtovana sredstva v EUR & Izplačana sredstva v EUR \\
\hline Ukrep 3.1. & 17.129 .338 & 16.069 .787 \\
\hline Ukrep 3.2. & 16.820 .704 & 16.820 .346 \\
\hline Ukrep 3.3. & 9.227 .854 & 9.221 .432 \\
\hline Ukrep 3.4. & 3.248 .778 & 3.240 .190 \\
\hline Ukrep 3.5. & 711.512 & 711.513 \\
\hline Ukrep 3.6. & 408.159 & 310.949 \\
\hline Ukrep 3.7. & 4.214 .064 & 4.851 .163 \\
\hline SKUPAJ & 51.760 .409 & 51.225 .380 \\
\hline
\end{tabular}

Vir: Služba Vlade RS za lokalno samoupravo in regionalno politiko (2010, str. 57)

Glede na to, da ni javno dostopnih podatkov o uspešnosti črpanja EPD 2004-2006 po posameznih letih v posameznih članicah EU, razen za leto 2006, je v prispevku predstavljena kumulativna uspešnost črpanja do 31. 12. 2006. Kot je razvidno iz grafikona 1, je bila leta 2006 pri črpanju sredstev iz EKUJS najbolj uspešna Latvija, saj je izplačala 74 \% vseh sredstev, ki jih je za izvajanje tretje prednostne naloge EPD 2004-2006 načrtovala pridobiti iz EKUJS. Malo slabše sta se odrezali Estonija z 71 \% izplačanih sredstev ter Madžarska s 70 \% izplačanih sredstev, ki sta jih načrtovali izplačati iz EKUJS. RS je bila leta 2006 zelo slaba pri črpanju sredstev, saj je izplačala $39 \%$ vseh načrtovanih sredstev iz EKUJS. Slabša od nje je bila Malta, ki je izplačala 37 \% načrtovanih sredstev. Stopnja črpanja na ravni EU-10 je bila 52 \%. To stopnjo so presegle Slovaška, Madžarska, Estonija in Latvija, za njo so zaostale Malta, RS, Češka, Litva in Poljska. 
Grafikon 1: Stopnja črpanja sredstev iz EKUJS za izvajanje tretje prednostne naloge EPD 2004-2006 v novih članicah EU-10 leta 2006 glede na skupna načrtovana sredstva

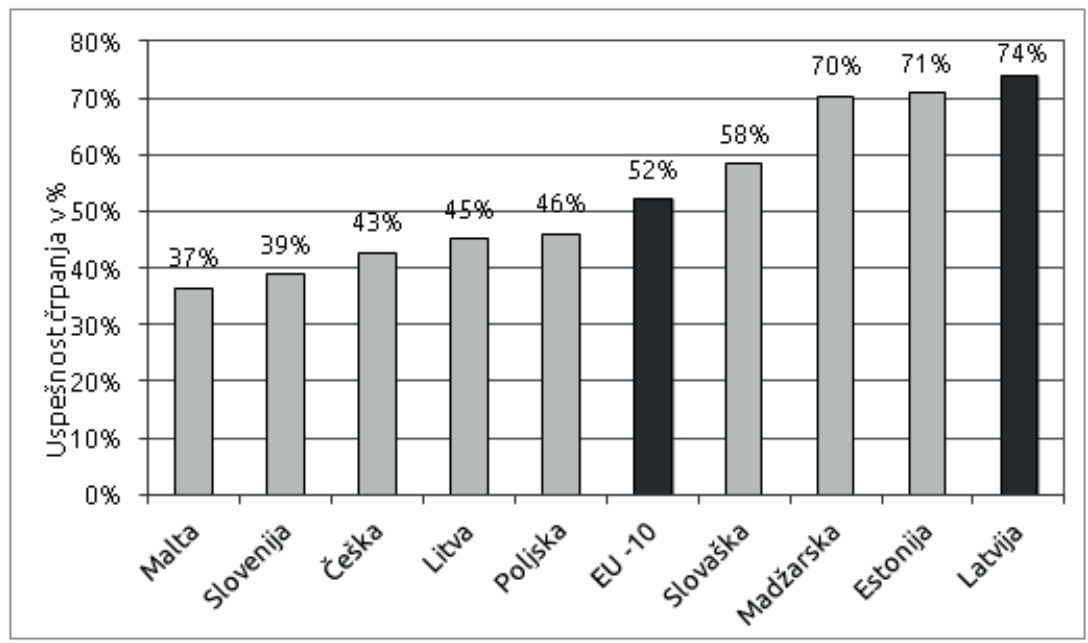

Vir: European Union (2006, str. 357-358), European Union (2007, str. 321-322) in lastni izračuni

Vendar glede na zgoraj navedeno ne moremo sklepati, kakšno je bilo črpanje ob koncu EPD 2004-2006, saj so se določene obveznosti izplačevale tudi v kasnejših letih, ko so hkrati že potekali drugi programi.

\section{Grafikon 2: Stopnja izplačanih EU sredstev po posameznih letih za izvajanje PRP 2004-2006 v RS}

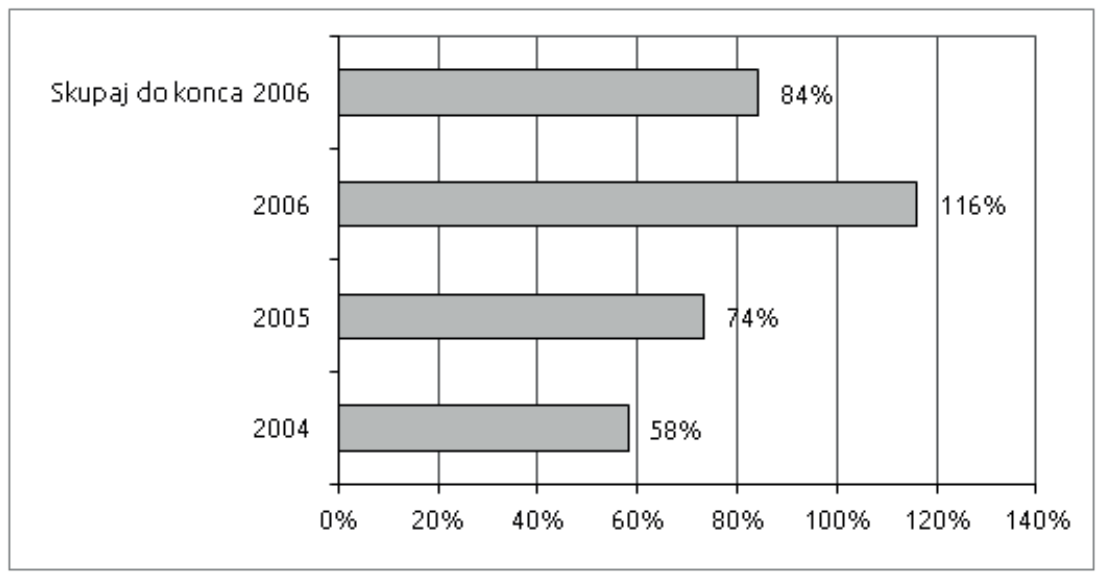

Vir: European Union (2007, str. 329) in lastni izračuni

RS je za izvajanje PRP 2004-2006 skupaj načrtovala 281,6 mio EUR. Od tega je bilo za leto 2004 načrtovanih 84,7 mio EUR, za leto 2005 94,4 mio EUR in za leto 2006 102,5 mio EUR. Iz grafikona 2 je razvidno, da je bila RS v obdobju 
2004-2006 pri črpanju sredstev relativno uspešna. Leta 2004 je RS izplačala 58 \% načrtovanih sredstev, leta 200574 \% načrtovanih sredstev, leta 2006 pa je RS izplačala 16 \% več, kot je načrtovala. Skupaj je RS do konca leta 2006 izplačala 84 \% vseh načrtovanih sredstev (Računsko sodišče, 2010c, str. 45).

Za izvajanje PRP 2004-2006 novih članic EU-10, ki so leta 2004 vstopile v EU, je bilo skupaj namenjenih 5,8 milijard EUR. RS je iz EKUJS dobila $5 \%$ vseh načrtovanih sredstev EKUJS, ki so bila namenjena izvajanju PRP 2004-2006 (European Union, 2007, str. 329). Za izvajanje ukrepov PRP 2004-2006 so se odločile vse nove članice EU-10. Iz grafikona 3 je razvidno, da je bilo na ravni EU-10 do konca leta 2006 izplačanih 72 \% načrtovanih sredstev iz EKUJS. Najbolj uspešna med novimi članicami EU je bila RS, ki je do konca leta 2006 izplačala 84 \% načrtovanih sredstev. RS sta sledili Češka, ki je izplačala $75 \%$ načrtovanih sredstev ter Poljska, ki je izplačala 73 \% načrtovanih sredstev. Najmanj uspešna članica pri črpanju oziroma pri izplačilih iz EKUJS je bil Ciper, ki mu je do konca leta 2006 uspelo izplačati $56 \%$ načrtovanih sredstev iz EKUJS. Slabše od povprečja EU-10 so bile pri izplačilih iz EKUJS Litva, Latvija in Slovaška, ki so do konca leta izplačale manj kot 70 \% načrtovanih sredstev iz EKUJS. 1 \% pod povprečjem EU-10 sta bili Estonija in Madžarska, ki sta izplačali 71 \% načrtovanih sredstev (Računsko sodišče, 2010c, str. 51). Glede na zgoraj navedeno ne moremo sklepati, kakšno je bil črpanje ob koncu izvajanja PRP 2004-2006, saj so se določene obveznosti izplačevale še v kasnejših letih, ko so hkrati že potekali drugi programi. Nekatere obveznosti iz tega programa so se izplačevale do konca leta 2010, saj so bile določene petletne obveznosti sklenjene še v letu 2006.

Grafikon 3: Delež izplačanih sredstev iz EKUJS za izvajanje PRP 2004-2006 po posameznih članicah EU-10 do konca leta 2006

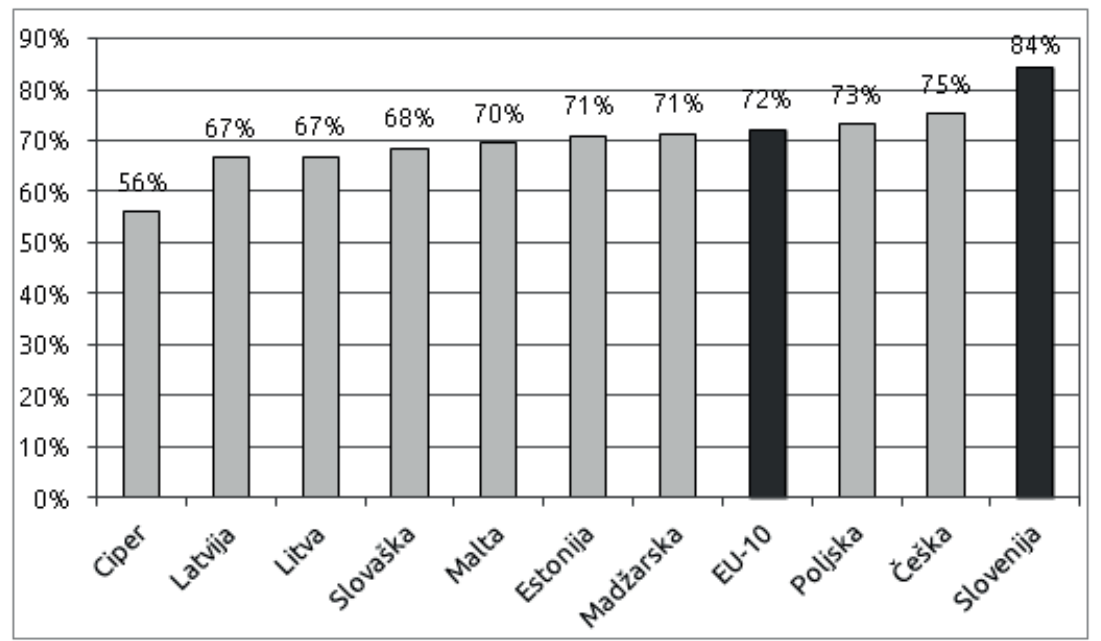

Vir: European Union (2007, str. 329) in lastni izračuni 


\subsection{Uspešnost črpanja sredstev PRP 2007-2013}

Glavni cilji SKP razvoja podeželja $v$ trenutnem programskem obdobju so: izboljšanje konkurenčnosti kmetijstva in gozdarstva s podporo za prestrukturiranje, razvoj in inovacije, izboljšanje okolja in pokrajine s podporo za upravljanje z zemljišči in izboljšanje kakovosti življenja na podeželskih območjih in spodbujanje diverzifikacije gospodarskih dejavnosti. Za vsak zgoraj navedeni cilj je oblikovana tematska os, v kateri so med seboj povezane skupine ukrepov s posebnimi usmeritvami, ki naj bi prispevali k uresničevanju enega ali več ciljev. Za dosego teh ciljev so bile oblikovane tri osi, in sicer prva, druga in tretja, dodatno pa je bila oblikovana še četrta os za krepitev razvojnih spodbud (LEADER). Skupni obseg vseh razpoložljivih sredstev za sedemletno programsko obdobje tako znaša 1,2 milijarde evrov (Računsko sodišče, 2010).

Slika 1: Struktura Programa razvoja podeželja 2007-2013

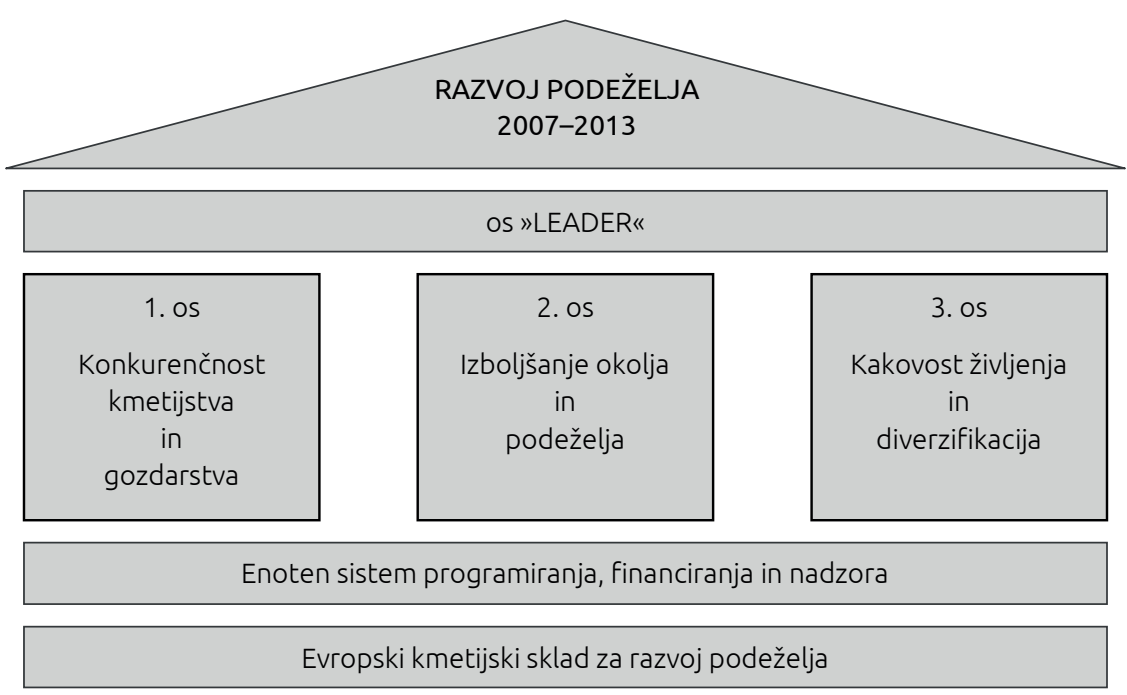

Vir: MKO (2007a, str. 6)

Če pogledamo uspešnost črpanja sredstev EKRSP RS po posameznih letih, je iz grafikona 4 razvidno, da se stopnja uspešnosti povečuje. Leta 2007 je bilo izplačanih samo 20 \% načrtovanih sredstev za leto 2007, leta 2008 je stopnja izplačil narasla na $49 \%$, če gledamo kumulativno oziroma skupaj načrtovana sredstva za leto 2007 in 2008. Do konca leta 2009 je RS izplačala 62 \% sredstev, ki so bila načrtovana do konca leta 2009. Če gledamo stopnjo izplačanih sredstev EKSRP glede na vsa načrtovana sredstva v obdobju 2007-2013, stopnja izplačanih sredstev prav tako narašča. Leta 2007, na začetku izvajanja PRP 2007-2013, je bila stopnja izplačanih sredstev samo 3 \%, leto kasneje je delež narasel na $16 \%$, leta 2009 na $28 \%$ sredstev EKSRP, ki so načrtovana za obdobje 2007-2013 iz tega sklada. 


\section{Grafikon 4: Kumulativne stopnje črpanja sredstev RS iz EKSRP od 2007 do 2009}

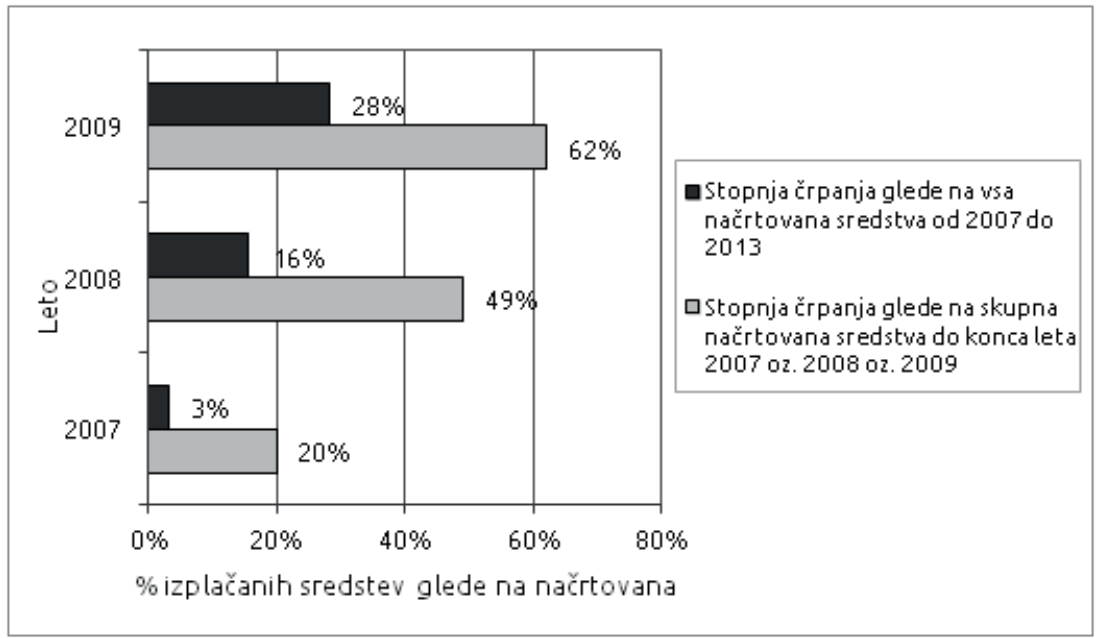

Vir: European Union, 2010 in lastni izračuni

Kot je razvidno iz grafikona 5, je bilo na ravni EU-27 do konca leta 2009 skupaj izplačanih $21 \%$ vseh sredstev iz EKSRP, ki so bila načrtovana za izvajanje ukrepov v obdobju 2007-2013. Pri črpanju so bolj uspešne stare članice oziroma EU-15, saj je njihova stopnja črpanja nad povprečno stopnjo EU-27 in znaša malenkost več, to je $23 \%$. Da so stare članice bolj uspešne, je razvidno iz tega, da so na prvih sedmih mestih Irska, ki je izplačala $44 \%$ načrtovanih sredstev, sledi ji Luksemburg s $40 \%$, Avstrija z $38 \%$, Finska s $33 \%$, Belgija z $32 \%$ in Švedska z 29 \% izplačanih sredstev glede na načrtovana sredstva v obdobju 2007-2013. Nove članice EU-12 so pri črpanju trenutno manj uspešne, saj so v povprečju izplačale samo $16 \%$ načrtovanih sredstev za obdobje 2007-2013. Na prvem mestu med novimi članicami je RS, ki je do konca leta 2009 izplačala 28 \% vseh načrtovanih sredstev, hkrati pa je tudi na osmem mestu med vsemi članicami EU-27. Takoj za RS je Slovaška, ki je izplačala 27 \% vseh načrtovanih sredstev. Na zadnjih treh mestih so Romunija, Bolgarija in Malta, ki so do konca leta 2009 izplačale manj kot $10 \%$ vseh načrtovanih sredstev v obdobju 2007-2013. Podatki o izplačanih sredstvih glede na načrtovana sredstva po posameznih letih so zelo podobni. 
Grafikon 5: Stopnja izplačanih sredstev do 31.12.2009 glede na skupna načrtovana sredstva $v$ obdobju od 2007 do 2013 iz EKSRP po posameznih članicah

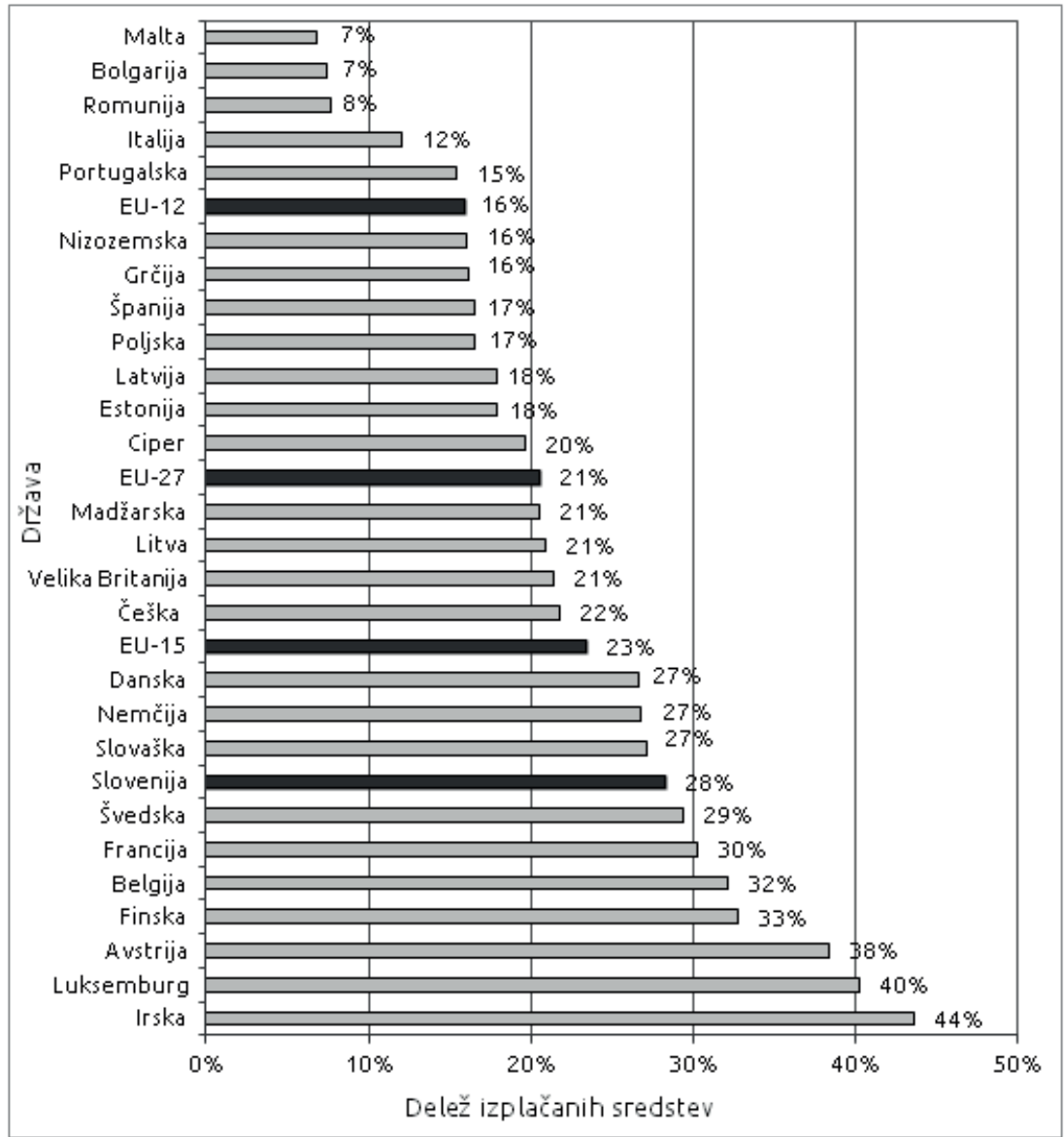

Vir: European Union, 2010 in lastni izračuni

\subsection{Ukrepi za boljše črpanje sredstev v RS}

Večina članic je imela določene težave pri črpanju evropskih sredstev v prvih letih po vstopu v EU, in sicer predvsem zaradi pomanjkanja dolgoročnih vizij pristojnih organov, pomanjkanja privatnih finančnih virov, slabe administrativne usposobljenosti pristojnih organov na nacionalni in regionalni ravni, slabe koordinacije med pristojnimi organi, napak pri javno-zasebnem partnerstvu, omejenih človeških virih itd. (Zaman, v Cace et al., 2010, str. 90). Posamezne članice imajo pomisleke glede smotrnosti dolgoročnega oblikovanja programov razvoja podeželja, po drugi strani pa EK zavzema stališče, da je potreben namenski oziroma ciljno usmerjen pristop oblikovanja politike razvoja podeželja s poudarkom na zasebnem sofinanciranju in na t. i. pristopu od »spodaj navzgor«, pri katerem imajo veliko vlogo lokalne 
skupnosti. S tem se v primeru spremenjenih zunanjih okoliščin zagotovi večja učinkovitost (Schrader, 1994, str. 364). Veliko članic in držav kandidatk se je soočilo oziroma se sooča s problemom absorpcijske sposobnosti, ki se kaže v uspešnosti in učinkovitosti črpanja razpoložljivih sredstev iz evropskih skladov (Mrak \& Horvat, 2009, str. 86).

RS je porabila vsa razpoložljiva evropska sredstva za izvajanje programov razvoja podeželja, in sicer programa SAPARD, EPD 2004-2006 in PRP 2004-2006. Pri programu, ki se izvaja trenutno, pa je RS delno uspešna. RS je bolj uspešna pri črpanju ukrepov 2. osi, manj pa pri izvajanju nekaterih ukrepov 1. osi in 3. osi. Vzroki za manj uspešno črpanje na teh dveh oseh so (Računsko sodišče, 2010 in 2010a): nepravočasno informiranje MKO o terminskih planih javnih razpisov, nezadostno informiranje MKO o ukrepih, prenizka stopnja sofinanciranja, nepoznavanje ukrepov, prezahtevni razpisni pogoji, neustrezna svetovalna podpora in neustreznost prispelih vlog. Zato je MKO, tudi na podlagi zahtev Računskega sodišča Republike Slovenje, sprejelo ustrezne ukrepe, da se poveča uspešnost črpanja sredstev na 1., 3., in 4. osi. Ti so predvsem naslednji: povečanje deleža sofinanciranja, izobraževanje javnosti o posameznih ukrepih PRP 2007-2013 (predvsem občin), dialog s potencialnimi prijavitelji, da bi bilo manj nepopolnih vlog, poenostavitev razpisnih pogojev, objava terminskih planov o tem, kdaj bodo objavljeni določeni javni razpisi ter prerazporejanje sredstev med ukrepi, kjer je slabo črpanje, na tiste, kjer je črpanje sredstev bolj uspešno (Računsko sodišče, 2010 in 2010b; Razvojna agencija Slovenske Gorice, 2010).

Pri analizi uspešnosti črpanja posameznih ukrepov je razvidno, da je uspešnost črpanja najboljša pri tistih ukrepih, ki so se že izvajali v preteklih programih razvoja podeželja v obdobju 2003-2007, saj so tu naložbe in priprava vlog preprostejša, s tem pa je tudi večji interes vlagateljev (Računsko sodišče, 2010). Poleg tega pa je treba upoštevati, da se je črpanje dejansko začelo šele leta 2008, saj je bil PRP za RS potrjen šele septembra 2007. (MKO, 2010; MKO, 2008).

\section{Zaključek}

RS je evropska sredstva za razvoj podeželja izplačevala oziroma jih izplačuje na podlagi različnih programskih dokumentov, ki so oziroma veljajo v različnih programskih obdobjih. Programu SAPARD, na podlagi katerega so se sredstva izplačevala v predpristopnem obdobju EU 2000-2003, so sledili še trije programski dokumenti. V obdobju od 2004 do 2006 je RS evropska sredstva za razvoj podeželja izplačevala na podlagi EPD 2004-2006 v okviru tretje prednostne naloge ter v okviru PRP 2004-2006. V trenutnem programskem obdobju, ki velja do konca leta 2013, RS evropska sredstva za razvoj podeželja izplačuje na podlagi PRP 2007-2013. Sredstva, ki so bila na voljo na podlagi programa SAPARD, je RS dobro izkoristila, saj je izplačala vsa sredstva, ki so bila načrtovana oziroma je izplačala še celo 11 \% sredstev več, kot je načrtovala. 
V okviru EPD 2004-2006 je RS izplačala 99 \% načrtovanih sredstev, čeprav podatki za leto 2006 kažejo, da je do takrat izplačala samo 39 \% načrtovanih sredstev in da je bila na predzadnjem mestu med članicami EU-10, ki so ta program izvajale. Vendar pa je treba upoštevati, da je šlo tukaj za večletno izvajanje in da so se obveznosti, ki so se sicer sklenile pred koncem leta 2006, izplačevale tudi še kasneje, saj gre za večletne pogodbene obveznosti. Na podlagi PRP 2004-2006 je RS do konca leta 2006 izplačala 84 \% načrtovanih sredstev, vendar je tudi tukaj treba upoštevati, da so se sredstva izplačevala tudi še po tem letu, saj gre pri tem programu za petletne obveznosti in nekatere od teh so se končale šele leta 2010. V trenutnem programskem obdobju 2007-2013 je bila RS delno uspešna pri črpanju sredstev PRP 2007-2013. Ob koncu leta 2009 je RS izplačala 28 \% vseh načrtovanih sredstev v programskem obdobju oziroma 62 \% sredstev, ki so bila na voljo do konca tega leta. Če RS v trenutnem programskem obdobju primerjamo z drugimi članicami EU-27, je bila RS ob koncu leta 2009 nad povprečjem EU-12 in EU-27, ter tudi nad povprečjem EU-15, saj je bila tega leta RS po uspešnosti črpanja na osmem mestu med vsemi članicami ter prva med novimi članicami. Večina članic je imela določene težave pri črpanju evropskih sredstev v prvih letih po vstopu v EU, in sicer predvsem zaradi pomanjkanja dolgoročnih vizij pristojnih organov, pomanjkanja privatnih finančnih virov, slabe administrativne usposobljenosti pristojnih organov na nacionalni in regionalni ravni, slabe koordinacije med pristojnimi organi, napak pri javno-zasebnem partnerstvu, omejenih človeških virov. Zato so bili sprejeti v RS ukrepi za izboljšanje črpanja. Ti so povečanje deleža sofinanciranja, izobraževanje javnosti o posameznih ukrepih PRP 2007-2013 (predvsem občin), dialog s potencialnimi prijavitelji, poenostavitev razpisnih pogojev, objava terminskih planov o tem, kdaj bodo objavljeni določeni javni razpisi, ter prerazporejanje sredstev med ukrepi, kjer je slabo črpanje, na tiste, kjer je črpanje sredstev bolj uspešno. Na koncu lahko zaključimo, da je RS pri črpanju evropskih sredstev za razvoj podeželja relativno uspešna, vendar pa so potrebne izboljšave oziroma odprava določenih težav pri posameznih ukrepih. 
Izr. prof. dr. Aleksander Aristovnik je doktor ekonomskih znanosti, zaposlen na Fakulteti za upravo Univerze v Ljubljani kot docent za področje ekonomike javnega sektorja. Prav tako je izredni profesor za področje mednarodne ekonomije na Ekonomski fakulteti Univerze v Ljubljani. Je avtor oz. soavtor številnih domačih in tujih člankov ter delov monografij. V svojem raziskovalnem delu se ukvarja predvsem s področjem mednarodne ekonomije, ekonomike javnega sektorja, javnih financ in procesov evropskega integriranja. Dr. Aristovnik je (so)avtor več kot 360 bibliografskih enot in med njimi je okoli 40 člankov v revijah, ki jih indeksirajo SSCI, IBSS in Econlit baze.

Mag. Maja Žibert je zaposlena na Ministrstvu za kmetijstvo in okolje. Leta 2001 je diplomirala na Visoki upravni šoli na visokošolskem programu, leta 2004 pa na univerzitetnem študijskem programu Politologija, smer Analiza politik in javna uprava na Fakulteti za družbene vede. Leta 2008 je nadaljevala podiplomski magistrski študij Uprava na Fakulteti za upravo, kjer je leta 2012 pridobila znanstveni naslov magistrica znanosti. 


\section{Literatura in viri}

- Cace, C., Cace, S., Iova, C. \& Nicolaescu, V. (2010). Capacity of Phare and structural funds absorption: pre-accession versus post-accession. Lumen Publishing House. On behalf of »Alexandru loan Cuza« University, Department of Sociology and Social Work and Holt Romania Foundation.

- Council for the Rural Area (2010). Comparative analysis. Cap implementation in the EU-27 Member States. Pridobljeno 25. 10. 2010, s http://www.rlg.nl/cap/ analysis.html.

- Erjavec, E., Juvančič, L., Rednak, M. \& Volk, T. (2007). »Zdravstveni pregled« skupne kmetijske politike - v kakšnem stanju SKP pričakuje izzive prihodnosti? V Kavčič, S. (ur.). Slovensko kmetijstvo in podeželje v Evropi, ki se širi in spreminja. Domžale: Društvo agrarnih ekonomistov - DAES.

- European Commission (2000). SAPARD programmes 2000-2006-Estonia. Directorate-General for Agriculture, Unit B1. Pridobljeno 25. 10. 2010, s http://ec.europa.eu/agriculture/external/enlarge/countries/estonia/overview/ est_en.pdf

- European Commission (2000a). SAPARD programmes 2000-2006-Czech Republic. Directorate-General for Agriculture, Unit B1. Pridobljeno 25. 10. 2010, s http://ec.europa.eu/agriculture/external/enlarge/countries/ czech/overview/czrep.pdf

- European Commission (2007). Managing the Agriculture budget wisely. Directorate-General for Agriculture and Rural Development. Luxembourg: Office for Official Publications of the European Communities.

- European Commission (2007a). The European Union's Financial Framework 2007-2013. Luxembourg: Office for Official Publications of the European Communities.

- Evropska Komisija (2011a). Politika razvoja podeželja 2007-2013. Pridobljeno 17. 1. 2011, s http://ec.europa.eu/agriculture/rurdev/index_sl.htm

- Evropska Komisija (2011b). Skupna kmetijska politika in kmetijstvo EU - Stroški SKP. Pridobljeno 28. 11. 2011, s http://ec.europa.eu/agriculture/faq/cost/ index_sl.htm

- European Union (2006). Rural Development in the European Union. Statistical and Economic Information. Report 2006. Directorate-General for Agriculture and Rural Development. Pridobljeno 21. 9. 2010, s http://ec.europa.eu/ agriculture/agrista/rurdev2006/RD_Report_2006.pdf

- European Union (2007). Rural Development in the European Union. Statistical and Economic Information. Report 2007. Directorate-General for Agriculture and Rural Development. Pridobljeno 21. 9. 2010, s http://ec.europa.eu/ agriculture/agrista/rurdev2007/RD_Report_2007.pdf

- European Union (2010). Rural Development in the European Union. Statistical and Economic Information. Report 2010. Directorate-General for Agriculture and Rural Development. Pridobljeno 17. 11. 2010, s http://ec.europa.eu/ agriculture/agrista/rurdev2010/RD_Report_2010.pdf

- Heijman, W. \& Koch, T. (2011). The allocation of financial resources of the EU Structural Funds and Cohesion Fund during the period 2007-2013. Agricultural Economics - Zemedelska Ekonomika 57(2), str. 49-56.

- Markovič Hribernik, T., Kirbiš, M. \& Vek, U. (2008). Institutional Regulation and the Effectiveness of Absorbing EU Funds: The Experiences of Ireland, Estonia and Slovenia. Društvena Istraživanja, leto 2008, št. 6., 1219-1239. 
- MKO (2007). Končno poročilo o izvajanju programa SAPARD. Pridobljeno 21. 9. 2010, s http://www.mf.gov.si/slov/suseu/Koncno_porocilo_SAPARD29_6_2007-cistopis.pdf. Ljubljana: Ministrstvo za kmetijstvo, gozdarstvo in prehrano.

- Ministrstvo za kmetijstvo, gozdarstvo in prehrano (2007a). Nacionalni strateški načrt razvoja podeželja 2007-2013. Ljubljana: Ministrstvo za kmetijstvo, gozdarstvo in prehrano.

- Ministrstvo za kmetijstvo, gozdarstvo in prehrano (2008). Zapisnik 2. seje Nadzornega odbora za Program razvoja podeželja RS za obdobje 2007-2013. Pridobljeno 21. 9. 2010, s http://www.mkgp.gov.si/fileadmin/mkgp.gov.si/ pageuploads/PRP/Nadzorni_odbor/Zapisnik_2._seja.pdf

- Ministrstvo za kmetijstvo, gozdarstvo in prehrano (2010). Poročilo o vmesnem vrednotenju Programa razvoja podeželja 2007-2013. Pridobljeno 13. 10. 2011, s http://ec.europa.eu/agriculture/rurdev/countries/sl/mte-rep-sl_sl.pdf

- Mrak, M. \& Horvat, A. (2009). Macroeconomic and Financial Absorption Capacity of Turkey for the Use of EU Structural Funds. Eastern European Economics 47(4), 86-113.

- Računsko sodišče Republike Slovenije (2010). Revizijsko poročilo-Razvoj podeželja v Republiki Sloveniji. Pridobljeno 17. 11. 2010, s http://www.rs-rs.si/ rSrs/rsrs.nsf/I/K612CACE2B64A34B9C125771F005F99F5/\$File/OhrRzvPodez_ RSP.pdf

- Računsko sodišče Republike Slovenije (2010a). Razvoj podeželja v Republiki Sloveniji. Predstavitev revizijskega poročila. Pridobljeno 21. 9. 2010, s http:// www.rs-rs.si/rsrs/rsrs.nsf/N/K27744C9D15D82DC0EC125772000319C32/\$File/ Predstavitev_Razvoj_podezelja.pdf

- Računsko sodišče Republike Slovenije (2010b). Porevizijsko poročiloPopravljalni ukrepi Ministrstva za kmetijstvo, gozdarstvo in prehrano. Pridobljeno 21. 9. 2010, shttp://www.rs-rs.si/rsrs/rsrs.nsf/l/K15ADB083EDCFEB64C12577 970039A6AA/\$file/OhrRzvPodez_RSP_porev.pdf

- Računsko sodišče Republike Slovenije (2010c). Revizijsko poročilo - Črpanje sredstev evropskega proračuna. Pridobljeno 21. 9. 2010, s http://www.rs-rs.si/ rsrs/rsrs.nsf///KD22C369387B21A1AC125776E00334B1A/\$File/EU_crpanje_ SP04-08.pdf

- Razvojna agencija Slovenske Gorice (2010). Razpisi in ukrepi Programa razvoja podeželja 2007-2013 kot priložnost za Slovenjegoriška kmetijska gospodarstva in splošno javnost. Pridobljeno 13. 10. 2010, s http://rasg.si/kmetijstvo/

- Služba Vlade RS za lokalno samoupravo in regionalno politiko (2010). Končno poročilo o izvajanju Enotnega programskega dokumenta Republike Slovenije za programsko obdobje 2004-2006. Pridobljeno 21. 9. 2010, s http://www. euskladi.si/publikacije/letna_porocila/download/LP2010_koncno.doc.

- Schrader, H. (1994). Impact Assessment of the EU Structural Funds to Support Regional Economic Development in Rural Areas of Germany. Journal of Rural Studies 10(4), 357-365.

- Trdan, A. (2002). Možnost predpristopne pomoči SAPARD pri prestrukturiranju podeželja v državah kandidatkah. Diplomsko delo. Ljubljana: Univerza v Ljubljani, Ekonomska fakulteta.

- Zelenika, R. (2000). Metodologija i tehnologija izrade znanstvenog in stručnog djela. Rijeka: Ekonomska fakulteta.

- Wostner, P. (2005). Kako do denarja EU. Ljubljana: GV Založba. 


\title{
THE EFFECTIVENESS OF DISBURSEMENT OF THE EUROPEAN FUNDS FOR RURAL DEVELOPMENT BY SLOVENIA IN THE PERIOD 2003-2009
}

\author{
Key words: SAPARD, SPD, Rural Development Programme, effectiveness, disbursing \\ EU funds, rural development policy
}

For over 40 years the Common Agricultural Policy (hereinafter: the CAP) has been the most important European common policy. Agriculture is the only sector entirely financed from the EU budget. This means that EU funds substitute national funds. Therefore, a large proportion of the EU budget is earmarked for implementation of the CAP, even though it has been decreasing over the years. In 1984 it equalled 71 percent, at present it accounts for 40 percent and, in 2013, it will drop to only about 33 percent of the total EU budget. In the current 2007-2013 financial framework, the funds aimed at promoting growth and employment have for the first time exceeded those allocated to implementation of the CAP. Today the financing of the agricultural policy is underpinned by two funds that form part of the general EU budget, namely the European Agricultural Guarantee Fund and the European Agricultural Fund for Rural Development (hereinafter: the EAFRD). The former finances direct payments to farmers and measures to regulate agricultural markets (export and intervention refunds etc.), whereas the latter finances actions in the field of rural development in the EU member states (hereinafter: the Member States). In the financial period 2007-2013, EUR 862.4 billion were earmarked for financing the entire agricultural policy, of which EUR 88.3 billion or 10.2 percent went to rural development (European Commission, 2007; European Commission, 2007a; European Commission, 2011b).

The purpose of the article was to analyse the effectiveness of disbursing EU funds for rural development that were allocated to the Republic of Slovenia from 2003 to the end of 2009. Since the rural development policy is part of the CAP, another purpose was to analyse the success of the Republic of Slovenia in disbursing these funds in the past and the present when compared to other Member States. Namely, the article aimed to establish whether the Republic of Slovenia was successful in disbursing the funds within the Rural Development Programme in the period 2003-2009 and what was its success rate compared to other Member States.

Theoretically, every Member State can decide to pursue its own completely autonomous rural development policy. However, this would not function properly in practice because not every Member State could afford the policy it would in fact need. Many areas discussed by the rural development policy extend beyond the national and regional borders and affect the lives of people 
from other Member States. Moreover, every Member State has to overcome a number of its own physical, climatic and socioeconomic obstacles and deal with the different levels of development of its individual agricultural branches. For the above reasons, the EU pursues a common rural development policy which, nevertheless, confers large powers to the Member States (European Commission, 2011a; Council for the Rural Area, 2010). Every Member State has to overcome specific difficulties in its agriculture, along with differing levels of development and competitiveness and, therefore, the programmes differ from each other. Depending on the development level, the Member States have chosen different measures to boost the development and competitiveness of their agriculture and rural areas (European Commission, 2000).

The Republic of Slovenia started disbursing funds for implementation of the EU rural development policy on the basis of the SAPARD pre-accession programme in 2003. The competent ministry appropriated the financial support from this programme for implementing measures geared at improving the competitiveness of the agricultural sector, economic diversification and the improvement of rural infrastructure (Court of Audit, 2010; Court of Audit, 2010c). The Republic of Slovenia decided to implement five of the 15 SAPARD measures. These included: Investments in agricultural holdings (Measure 1), Investments in the processing and marketing of agricultural and fishery products (Measure 2), Economic diversification of farms (Measure 5), Development and improvement of rural infrastructure (Measure 12) and Technical assistance (Measure 15). The Republic of Slovenia paid the beneficiaries of individual measures a total of EUR 42.2 million, that is EUR 4.2 million more than planned, exceeding the plan by 11 percent. The Republic of Slovenia was among the most successful countries, ranking third in 2003 in terms of the amount of paid funds, following Estonia and Latvia.

After Slovenia joined the EU in 2004, the SAPARD programme continued providing the measures under Priority 3 of the 2004-2006 Single Programme Document (SPD) geared towards the restructuring of agriculture, forestry and fisheries. In the framework of this programme seven measures were implemented, of which five were in the area of agriculture and two in the area of fisheries. In 2006 Latvia was the most successful country in drawing from the European Agricultural Guidance and Guarantee Fund (EAGGF) as it paid out 74 percent of all funds planned to be obtained from the EAGGF for the purpose of implementing the third 2004-2006 SPD priority. The Republic of Slovenia was not successful in disbursing the funds in 2006, paying out just 39 percent of the planned EAGGF funds. Malta ranked even lower, paying out 37 percent of the planned funds. The EU-10 disbursement rate was 52 percent.

A total of EUR 5.8 billion was earmarked for implementation of the 20042006 Rural Development Programme in the ten new Member States (EU-10) which joined the EU in 2004. The Republic of Slovenia obtained from the EAGGF 5 percent of all planned EAGGF funds that had been appropriated for 
implementation of the 2004-2006 Rural Development Programme (European Union, 2007, p. 329). All ten new Member States decided to implement the measures under the 2004-2006 Rural Development Programme. At the EU-10 level 72 percent of the funds planned from the EAGGF had been paid out by the end of 2006. The most successful of the new Member States was the Republic of Slovenia, paying out 84 percent of the planned funds by the end of 2006. It was followed by the Czech Republic and Poland, paying out 75 and 73 percent of the planned funds, respectively.

The three main objectives of the CAP in the area of rural development in the current programme period are as follows: improving the competitiveness of agriculture and forestry by supporting restructuring, development and innovation; improving the environment and the countryside by supporting land management; and improving the quality of life in rural areas and encouraging the diversification of economic activity. Each of the above objectives has a thematic axis that intertwines with groups of measures containing special guidelines that should contribute to the achievement of one or more goals. Three axes were established to accomplish these goals, namely Axis 1, 2 and 3, whereas a fourth axis was created subsequently to bolster the development incentives (LEADER). All available funds for the seven-year programme period thus total EUR 2 billion (Court of Audit, 2010). At the EU-27 level, 21 percent of all EAGGF funds that had been earmarked for implementation of the measures in the period 2007-2013 had been paid out by the end of 2006 . The old Member States, the EU-15, were more efficient in disbursing the funds given that their disbursement rate was higher than the EU-27 average. The new EU-12 Member States are currently less successful in disbursing the funds as they have paid out on average only 16 percent of the funds planned for the period 2007-2013. Among the new Member States, the first place was occupied by the Republic of Slovenia, paying out 28 percent of the planned figure by the end of 2009 and thus ranking eighth among all EU-27 Member States.

Most Member States had some difficulties in disbursing the European funds in the first year following their accession to the EU, mainly due to the lack of long-term vision of competent bodies, a scarcity of private financial sources, a low level of administrative qualifications of the competent bodies at the national and regional levels, poor co-ordination between the competent bodies, deficiencies in public-private partnerships, limited human resources etc. (Zaman in: Cace et al., 2010, p. 90). Some Member States have scruples about the expediency of the long-term designing of rural development programmes while, on the other hand, the European Commission maintains that a special-purpose or targeted approach is necessary in the making of the rural development policy, with an emphasis on private co-financing and the »bottom up approach where local communities play an important role. Based on requests by the Court of Audit of the Republic of Slovenia, the Ministry of Agriculture and the Environment (MAE) adopted appropriate 
measures to improve the success rate in disbursing funds from Axes 1, 3 and 4. These mainly include: an increase in the co-financing share, informing the public about individual measures of the 2007-2013 Rural Development Programme (especially the municipalities), dialogue with potential applicants to reduce the number of incomplete applications, simplification of the tender conditions, publication of publishing time schedules of concrete public tenders as well as the reallocation of funds from measures characterised by low disbursement to those where disbursement is more effective (Court of Audit, 2010 and 2010b, and Slovenske gorice Development Agency, 2010). It is clear from the analysis of the effectiveness of the disbursement of individual measures that the rate was higher with those measures that had already been implemented under the previous Rural Development Programmes over the period 2003-2007, because the investments and drawing up of applications were simpler, which in turn increased the interest of investors (Court of Audit, 2010). Moreover, it should be noted that disbursement only started in 2008 because the Rural Development Programme for the Republic of Slovenia was only approved in 2007 (MAE, 2010 and MAE, 2008). To conclude, the Republic of Slovenia has been relatively successful in disbursing the European funds for rural development, yet some improvements in managing should be introduced. 